\title{
Estanho na Amazônia: o apogeu e ocaso da produção
}

Carlos Romano Ramos - Graduação em Geologia pela UFPA e especialização em Geologia Econômica pela UFOP e Atualmente é pesquisador visitante da UFPA.

\section{Resumo}

No Brasil, na Região Amazônica, o minério de estanho (cassiterita) é obtido por dragagem em depósitos aluvionares, extração de minério primário e lavra de pequeno porte. O concentrado de estanho obtido $\left(\mathrm{SnO}_{2}\right.$, contendo $60 \%$ de estanho), sendo transformado, via redução, nos fornos elétricos, transformando-o em lingotes de estanho. O metal é primeiramente usado para a produção de folhas de flandres - chapas de aço recobertas com estanho e utilizadas para fabricação de latas para alimentos, bebidas e produtos químicos, bem como na produção de soldas e outras ligas para a indústria em geral (particularmente em segmentos elétricos e eletrônicos). A mina mais importante é a de Pitinga (pureza de $55,3 \%$ ), localizada a $300 \mathrm{~km}$ ao norte de Manaus (AM) e proprietária da Paranapenema. Pitinga dispõe de reservas provadas de columbita-tantalita, criolita e zirconita, contendo terras raras e itrium, cuja viabilidade econômica ainda está sendo estudada. Há inda veios mineralizados no estado de Rondônia, incluindo a mina de Bom Futuro (pureza de 58\%), no município de Ariquemes, onde operam os mineradores de pequeno porte. O Brasil é o quinto maior produtor do metal, após Indonésia, China e Peru.

Palavras-chave

Amazônia, estanho, ocaso e apogeu.

\section{Abstract}

In Brazil, in the Amazon Region, tin ore (cassiterite) is largely obtained by open-cast mining, via the dredging of alluvial deposits, extraction of primary ore or from small-scale prospecting. The resulting concentrate $\left(\mathrm{SnO}_{2}\right.$, which contains $60 \%$ tin) is then transformed, via reduction in electric furnaces, into tin ingots. The metal is primarily used for the production of tin plate - fine steel plates coated with tin and used in the manufacture of cans for food, beverages and chemical products, as well as in the production of solder and other alloys for industry in general (particularly the auto and electrical/electronic segments). The country's most important mine is Pitinga (purity of 55,3\%), located $300 \mathrm{~km}$ to the north of Manaus (AM) and owned by Paranapanema. Pitinga also has proven reserves of columbite-tantalite, cryolite and zirconite, containing rare earths and yttrium, whose economic feasibility is still being studied. There are also lodes in the state of Rondônia, including the Bom Futuro mine (purity of 58\%), in the municipality of Ariquemes, where the great majority of small and medium-scale prospectors operate. Currently, Brazil is the fourth largest producer, after Indonesia, China and Peru).

\section{Keywords}

Amazon, tin, sunset end apogee. 


\section{INTRODUÇÃO}

No final da década de 90 do século XX, o Brasil projetava-se como o quarto maior produtor de estanho em concentrado, após a China, a Indonésia e o Peru (USGS, 2002). Líder da produção de estanho no Brasil, o Grupo Paranapanema, criado em 1996, com ênfase em negócios na produção de metais não-ferrosos, principalmente cobre, zinco e estanho, passou a atuar por intermédio de três grandes divisões: Mamoré Mineração e Metalurgia Ltda. (estanho), Eluma S/A Indústria e Comércio (tubos e conexões de cobre e outras ligas) e Caraíba Metais S/A (cobre e subprodutos).

A Mamoré Mineração Ltda., nos anos 70, iniciou as atividades de mineração e metalurgia extrativa. A partir de 1977, a empresa deu prioridade à industrialização e ao comércio de estanho, associando-se à Paranapanema S/A, Mineração, Indústria e Construção, esta envolvida na pesquisa e lavra de estanho na Amazônia. Com a incorporação da Mamoré ao Grupo Paranapanema, duas empresas passaram a ser responsáveis pelas atividades de exploração mineral e metalurgia extrativa - a Mineração Taboca S/A e a Mamoré Mineração, respectivamente. Enquanto a Mineração Taboca S/A executa a pesquisa e a lavra de cassiterita (mineral-minério de estanho), tendo Pitinga (AM) como principal mina de estanho, a Mamoré Mineração e Metalurgia Ltda. transforma o concentrado de estanho em metal refinado, no município de Pirapora de Bom Jesus (SP). A mina de Bom Futuro (RO), de menor expressão, complementa a oferta de concentrado (Grupo Paranapanema, Relatório Anual 1996/2000). As minas de Pitinga e Bom Futuro são lavradas a céu aberto. O processo de extração e beneficiamento compreende a draga de sucção sobre plantas flutuantes, a concentração final por métodos gravimétricos e a separação magnética e eletrostática, produzindo-se o concentrado de cassiterita. Na fundição da Mamoré (SP), o concentrado é produzido em estanho metálico ou anodos.

As empresas controladas do segmento estanífero atuam nos mercados interno e externo, tendo um market share de $75 \%$ da demanda doméstica de alguns produtos.

Em 2002, o Grupo Paranapanema fazia parte do grupo das nove maiores empresas produtoras de estanho metálico. A Figura 1, a seguir, mostra a distribuição mundial das principais empresas produtoras de estanho.

Na década de 90, a produção nacional de concentrado de estanho sofreu um decréscimo significativo, da ordem de $12 \%$ a.a. Com a escassez da principal matéria-prima para a produção de estanho metálico, ocorreu a queda das exportações de lingotes de estanho, o que afetou principalmente a Divisão de Estanho (da Mamoré Mineração e Metalurgia Ltda. e da Mineração Taboca S/A), visto que o metal em lingote representa, 
em média, mais de 95\% das exportações totais (período 1995/2000). A sociedade controlada Mineração Taboca S/A goza de incentivo fiscal de redução de impostos indiretos até 2013, outorgado pelo Conselho de Desenvolvimento da Amazônia (CODAM). No setor de estanho, a questão estratégica é dispor de produção de cassiterita, daí a Divisão de Estanho ter apurado prejuízos, afetada pela redução do concentrado de estanho em virtude da exaustão das reservas e dos efeitos desfavoráveis dos preços do metal, além da desvalorização cambial ocorrida em 2002.

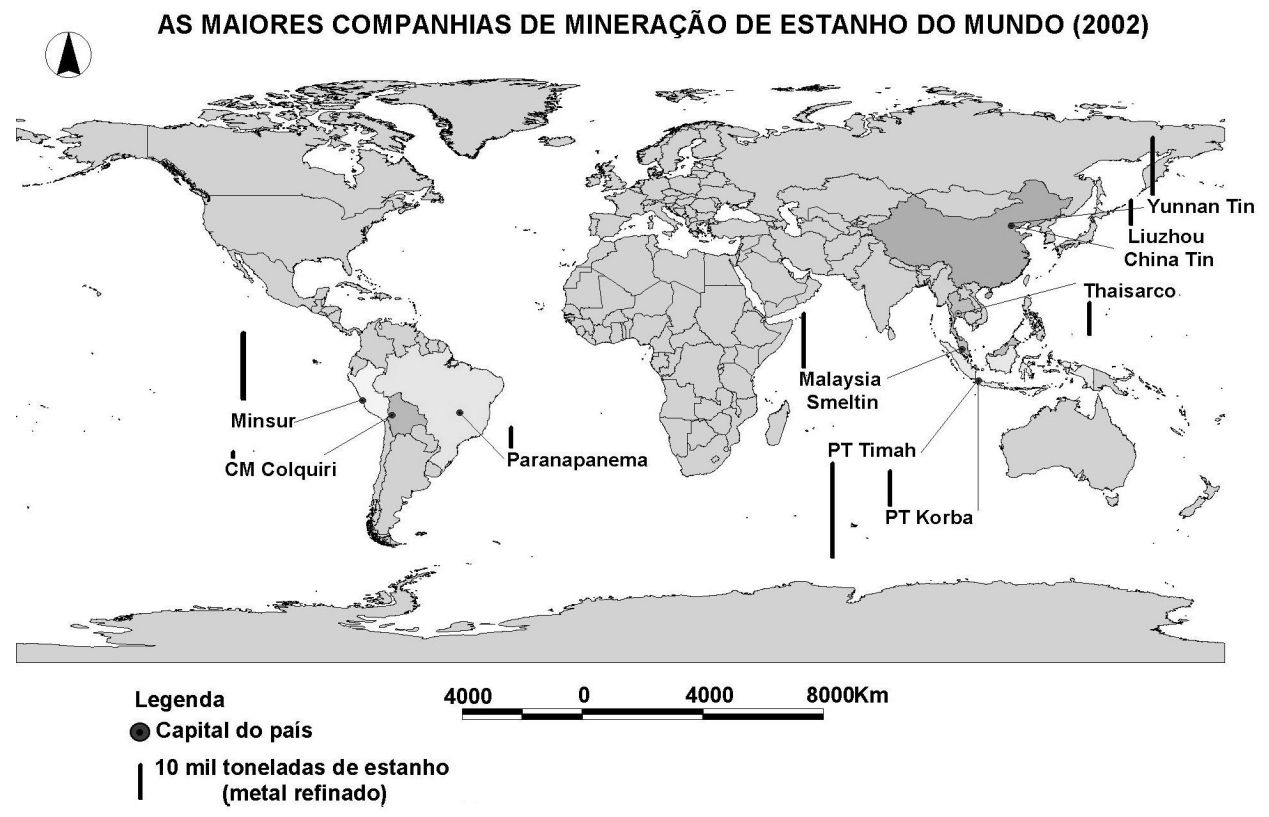

Figura 1: Distribuição mundial das principais empresas estaníferas produtoras de estanho refinado.

Fonte: Elaborado pelo autor.

A crise do estanho pode ser avaliada pela queda dos preços do metal. Em meados da década de 80, a Bolsa de Metais de Londres cotava o metal a US\$18.000/t. Hoje o preço do metal gira em torno de US\$ 5.600/t (LME), em decorrência de uma superoferta global de metal, principalmente por países asiáticos (China, Tailândia e Malásia), e da substituição do estanho por outros materiais em embalagens de alto consumo. A expansão da indústria eletrônica, com grande demanda por soldas à base de estanho, não aliviou a tendência global. A queda da produção nacional de estanho (de um pico de 45,7 mil toneladas em 1989 para 13,8 mil toneladas, um tombo de 70\%), devido à falta física de produto (estanho em concentrado), afetou o nível das exportações. Após um saldo recorde de exportações da ordem de US\$ FOB 286 milhões (1989), o comércio exterior brasileiro de estanho alcançou apenas US\$ FOB 32,6 milhões em 2000. 
Considerando a performance dos preços dos metais do gráfico, a seguir, o mercado do estanho apresenta especificidades semelhantes às do cobre e do zinco, por exemplo. O preço do estanho, em patamares da ordem de US\$ 5 mil a US\$ 6 mil/t, é inferior ao custo médio de muitos produtores.

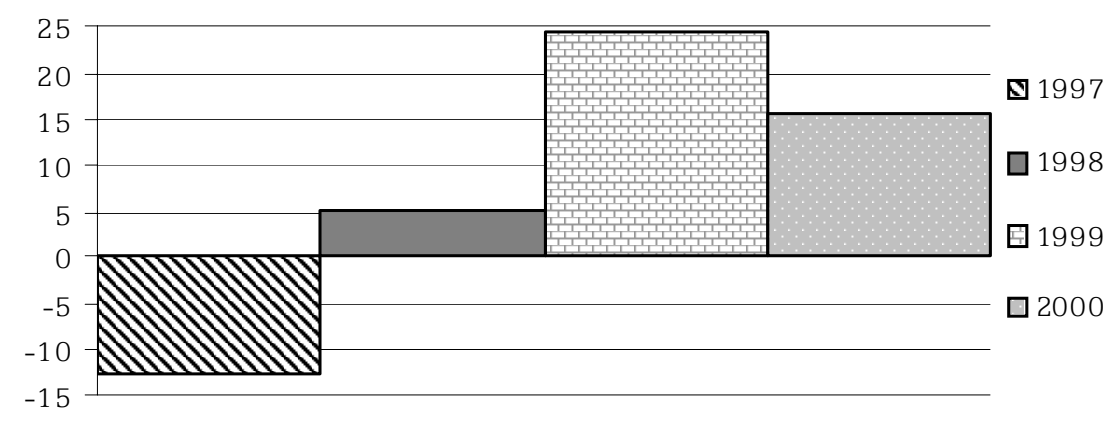

Gráfico 1: Evolução do EBITDA no período 1998/2000 (R\$ em milhões).

Fonte: Elaboracão do autor com base em (PARANAPANEMA, 2003).

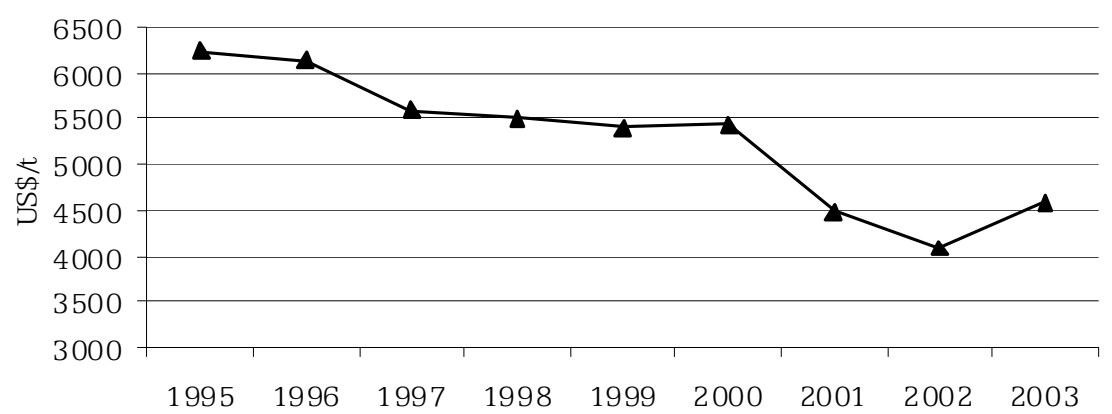

Gráfico 2: Evolução do preço (média anual) do estanho (US\$ LME). Fonte: Elaboração do autor com base em (PARANAPANEMA, 2003).

A CESBRA (Grupo BRASCAN) surgiu em 1951 para atender a demanda de estanho metálico da Companhia Siderúrgica Nacional. Em 1962, foi implantada a mina de Santa Bárbara, localizada a 120 quilômetros de Porto Velho, hoje esgotada. A mina atual de cassiterita da CESBRA fica no Estado de Rondônia, no município de Itapoá do Oeste. Atualmente, com as margens de lucro do estanho despencando, a estratégia foi driblar a crise causada pela queda do preço do metal e apostar nos segmentos químico e soldas, reduzindo sua exposição ao mercado de estanho metálico. A verticalização do processo é realizada pela ERSA, que transforma cassiterita em estanho metálico. A CESBRA participa com $12 \%$ da produção nacional do metal, dependendo de importações de concentrado de estanho para atender as necessidades, mas pretende atingir a auto-suficiência em 2007. Em 2002, a CESBRA teve um faturamento de $\mathrm{R} \$ 40$ milhões. 
O balanço da oferta-demanda mundial de estanho, para o período 1997/2004 (previsões para 2003/2004), estimado pela GFMS Metals Consulting (Gold Fields Mineral Services), mostra que, após dois anos de declínio dos preços do metal (2001 e 2002) , espera-se uma retomada no crescimento da demanda para 2003 e 2004 de 3,4\% e 3,3\%, respectivamente. O otimismo está sendo maior pelo lado da oferta. A produção do mundo ocidental ficará estável, visto que se espera um pequeno declínio na Malásia e na Tailândia, devido à escassez de concentrado. A Indonésia deverá aumentar a produção, com a retomada das atividades da Companhia PT Timah. O papel da China é sempre crítico para o mercado. A produção média anual brasileira de estanho em concentrado, nos dois primeiros anos do século XXI, foi de 14 mil toneladas, devendo permanecer nesse patamar em 2003/2004.

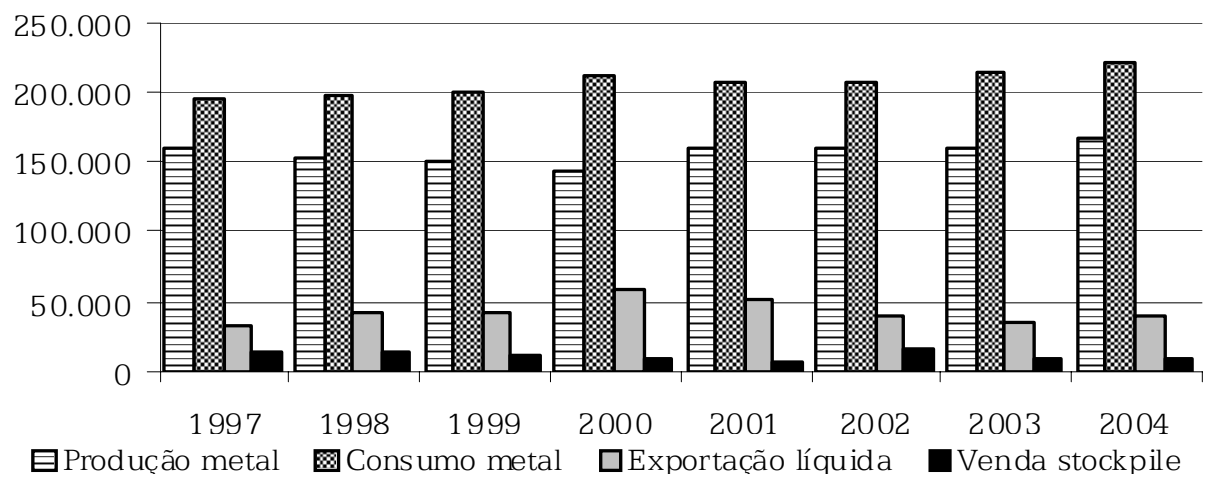

Gráfico 3: Balanço da oferta-demanda no período 1997/2004. Fonte: Elaboração do autor com base em (GFMS, 2004).

O consumo aparente de estanho metálico no Brasil, ao longo dos anos 90, é mostrado na Gráfico 4, a seguir.

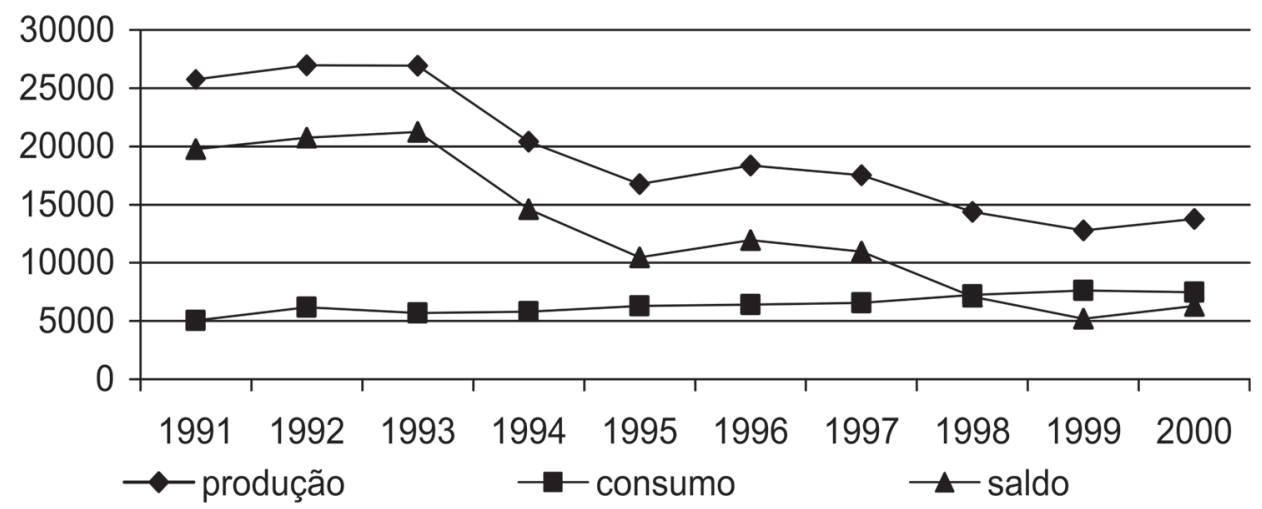

Gráfico 4: Balanço da produção-consumo de Sn-metálico na década de 90 (em toneladas).

Fonte: Elaboração do autor com base em (GFMS, 2003). 
O Brasil apresenta uma característica dual com relação ao balanço produção-consumo de estanho, pois, além de grande produtor, é um grande consumidor (além de exportador líquido). O esgotamento do minério de alto teor da mina de Bom Futuro, a escassez de reservas das aluviões mais ricas da jazida de Pitinga e o colapso dos preços do metal são as razões fundamentais para o comportamento da curva da produção (Gráfico 4).

A balança comercial brasileira de estanho apresenta dois momentos díspares ao longo do período 1988/2000. Nos três últimos anos da década de 80, as exportações atingiram uma média anual de 32 mil toneladas de estanho, com a geração de divisas líquidas e média anual no mesmo período de US\$ FOB 233,7 milhões. No três últimos anos da década de 90, a média das exportações ficou em cerca de 7 mil toneladas, com uma geração líquida de receita de US\$ FOB 31,3 milhões - um tombo de 78\% em quantidade e uma perda de divisas da ordem de $87 \%$. Ainda no mesmo período, o preço da tonelada de estanho exportada passou de US\$ FOB 7.303 para US\$ FOB 4.471, um decréscimo de quase 39\%. A distribuição do valor das exportações por produtos, em 2002, foi de US\$ FOB 35 milhões e o valor das exportações, em 2000, apresenta um perfil de pouco valor agregado, visto que o produto estanho não ligado representa $98,8 \%$ do valor das exportações e 98,8\% em peso.

\section{A CASSITERITA O ESTANHO METÁLICO E TRANSFORMADOS}

O mais importante mineral-minério de estanho, a cassiterita (dióxido de estanho/ $\mathrm{SnO}_{2}$ ), que apresenta uma dureza entre 6-7, densidade de 6,8-7,1 e brilho adamantino a submetálico, com coloração castanha ou preta, raramente vermelha, é formada em veios de alta temperatura, normalmente relacionada com rochas ígneas, como granitos e riólitos. A cassiterita também é encontrada em associação com o tungstênio. Quando as rochas contendo cassiterita são decompostas pela ação das águas e da oxidação, a cassiterita tende a ficar intacta e, eventualmente, é concentrada nos rios, formando depósitos denominados placers (depósito mineral sedimentar de origem fluvial, eluvial, aluvial, eólica, etc., resultante de concentração mecânica natural), da mesma maneira como ocorre com as pepitas de ouro.

O estanho, na forma metálica, é quimicamente inerte, não sendo, portanto, tóxico, sendo utilizado no revestimento de chapas de aço (estanhagem) destinadas à produção de embalagens para bebidas e alimentos. Dentre as diversas indústrias que utilizam o estanho, destacam-se a siderúrgica, a eletrônica, a automobilística, a naval e a química. Cada tipo de depósito de cassiterita tem suas próprias características técnicas de processamento. O minério bruto dos placers é concentrado por meio de lavagem, mesa vibratória e separação magnética e eletrostática, sendo o produto final a cassiterita pura. 
Quando a cassiterita é encontrada em rochas duras, o minério é reduzido com o uso de britagem e cominuição. Enquanto a recuperação da cassiterita, encontrada em placers, varia entre 90\% e 95\%, a recuperação em rochas duras, como na Bolívia, atinge 50\% (PEARCE, 1980, p. 755). A transformação da cassiterita em estanho é realizada por aquecimento com o carbono em temperatura variando de $1.200^{\circ}$ a $1.300^{\circ} \mathrm{C}$. O concentrado de cassiterita quase pura, oriundo de placers é reduzido diretamente. No caso de concentrados com impurezas, elas devem ser removidas antes da redução.

Os usos industriais do estanho estão concentrados (88\%) em folhas-de-flandres (40\%), soldas (28\%), pewter $(7 \%)$, químicos $(7 \%)$ e bronze (6\%). As folhas-de-flandres (tinplate) resultam do revestimento do aço por uma fina película de estanho puro, com grau de pureza de $99,9 \%$. O estanho confere às folhas propriedades anticorrosivas. O produto é destinado às industrias de embalagens. Uma tonelada de folha-de-flandres demanda de 4 a 4,5 kg de estanho. As características do estanho (baixo ponto de fusão e afinidade em formar ligas) favorecem a aplicação do metal em soldas (compostos de estanho e outro metal). As soldas têm grande aplicação nas indústrias eletrônica e automobilística. A "liga branca", denominada babbit, é utilizada na produção de mancais, soldas, peças ornamentais etc. Mais recentemente surgiram o estanho eletrolítico e os compostos organoestanosos, usados na indústria metalúrgica. A liga de bronze (Sn-Cu) é amplamente usada na construção de navios e na indústria química, e a liga de pewter (estanho, antimônio e cobre) já era utilizada no Império Romano. O estanho é aplicado na produção de tintas, plásticos e fungicidas. Tratase de um novo nicho do metal na indústria química, já representando cerca de 15\% da demanda mundial (DNPM, 2001, p. 4).

A primeira descoberta de estanho no Brasil é creditada a uma Carta Régia de 1765, outorgando o direito de pesquisar cassiterita (mineral-minério de estanho) a Domingos Ferreira, na comarca de São Paulo. No início do século XX, registra-se a descoberta de aluviões estaníferas no rio Camaquã, município de Encruzilhada Sul, Estado do Rio Grande do Sul, sustentando uma atividade de garimpagem. Em São João Del Rey (MG), filões de pegmatitos e placers estaníferos são descobertos na década de 40. Ainda hoje há uma produção artesanal de alto padrão de qualidade, reconhecida nacional e internacionalmente como uma das melhores do gênero, no fabrico do estanho (DNPM, 2001).

Ao final dos anos 50, ocorre a descoberta de cassiterita no Território Federal de Rondônia. Em meados da década seguinte, a produção nacional de cassiterita somava 2,8 mil toneladas, com Rondônia respondendo por aproximadamente 87\%, e Amapá, Goiás e Minas Gerais, por 13\% (DNPM, 1973, p. 26). Entre 1965 e 1969, a produção média anual de cassiterita 
no Território foi de 2,6 mil toneladas, com a extração do minério sendo realizada sob o regime de matrícula (garimpagem).

Em abril de 1970, por meio da Portaria Ministerial n. ${ }^{\circ} 195$, o Ministro das Minas e Energia (Antônio Dias Leite Júnior ) determina o fechamento, a partir de 31 de março de 1971, da então denominada província estanífera de Rondônia para as atividades de extração de cassiterita, pelo regime de matrícula, com base no Código de Mineração (Decreto Lei n. ${ }^{\circ} 227$, de 28 de fevereiro de 1967). A área da província estanífera de Rondônia abrangia o Território de Rondônia e parte dos Estados do Amazonas e do Mato Grosso.

A determinação ministerial foi cumprida na data fixada pelo Ministério das Minas e Energia (MME). Milhares de garimpeiros foram retirados, com o apoio de aviões militares, da província estanífera, tendo sido transportados para seus locais de origem (principalmente para o Estado do Maranhão), para os garimpos de ouro do rio Tapajós (município de Itaituba, no Estado do Pará) e para a região da Serra das Surucucus, em Roraima, em razão da descoberta de cassiterita. As ricas aluviões estaníferas de Surucucus, em áreas dos índios Ianomâmi, foram intensamente garimpadas (meados da década de 70), mas as atividades de garimpagem foram reprimidas pelo Governo Federal.

Em meados da década de 70, investigações geológicas desenvolvidas pelo Departamento Nacional da Produção Mineral (DNPM) e pela Companhia de Pesquisa de Recursos Minerais (CPRM) foram responsáveis pela descoberta da jazida estanífera de Pitinga, no Estado do Amazonas.

Data de 1963 a descoberta de cassiterita no Estado do Pará, no rio das Tropas, dando origem a uma incipiente produção do minério de estanho.

$\mathrm{Na}$ borda sul do Cráton Amazônico, granitos mineralizados em estanho (tin-bearing granites), localizados principalmente nos municípios de São Félix do Xingu e Altamira, bacia do rio Xingu, foram responsáveis por uma intensa atividade de produção de cassiterita (sistemas de garimpagem e empresarial). O Anuário Mineral Brasileiro de 2001 (DNPM) informa haver, ainda, uma reserva remanescente de aproximadamente 15,4 mil toneladas de reservas medidas (Sn-contido), concentrada no município de São Félix do Xingu (94\% da reserva medida total), mas não há registro de extração de cassiterita.

No Amapá, há duas regiões estaníferas nas bacias dos rios Amapari/ Araguari e Falsino (DNPM, 1976). A cassiterita encontra-se em pegmatitos, com ocorrência de greisens. O DNPM não registra a existência de reservas de cassiterita oficialmente aprovadas, bem como a produção de estanho em concentrado (Anuário Mineral Brasileiro, 2001).

Ao final dos anos 80, o Brasil torna-se o maior produtor mundial de estanho. A produção nacional atinge 54,7 mil toneladas de cassiterita, em estanho contido, mas a produção garimpeira ainda era responsável por $61 \%$ da produção total. 
Entre 1980 e 1989, a produção nacional de cassiterita, em estanho contido, exibiu uma taxa média anual de crescimento de 25,9\%, mas, entre 1989 e 1999, a produção registra uma taxa anual negativa de 13,2\%, em decorrência dos seguintes fatores: a) esgotamento dos teores mais ricos das minas de Pitinga e Bom Futuro, b) queda dos preços do metal e c) cerceamento da garimpagem. O preço do metal na Bolsa de Metais de Londres (LME), em valor corrente, no período 1989/2000, sofre uma queda de aproximadamente $37 \%$ (em termos reais, uma queda de 55\%, um tombo fantástico). Em 2001, a indústria de mineração de estanho enfrentaria mais uma crise no preço do estanho. Em maio de 2001, a cotação do metal alcançou US\$ 5000/t. No ano seguinte, no mês de setembro, o preço era cotado em US\$ 3.605/t.

A cotação atual (15 de agosto de 2003) do metal na Bolsa de Metais de Londres (LME) é de US\$ 4.825/t.

No final dos anos 80, o Brasil respondia por cerca de um quarto da produção mundial de estanho em concentrado, tornando-se o maior produtor mundial (SNIEE/ATCP). No limiar do século XXI, a posição brasileira, no rank dos produtores de concentrado de estanho, foi ultrapassada pela China (54,1 mil toneladas), pela Indonésia (47,9 mil toneladas) e pelo Peru ( 29.8 mil toneladas). Em 2001, segundo o Serviço Geológico dos Estados Unidos (USGS), a mina subterrânea peruana de San Rafael produziu 38 mil toneladas de estanho em concentrado, com reservas de 14 milhões de metros cúbicos, teor de estanho de 5\% e um custo de produção de US\$1.200 por toneladas métrica. Enquanto a produção brasileira, no período 1990/1999, amargava uma taxa média anual negativa de cerca de $-12 \%$, a produção peruana crescia a uma taxa média anual de aproximadamente 34\% (entre 1993 e 1999, a produção peruana foi multiplicada por seis).

\section{GEOLOGIA E RESERVAS MINERAIS: A PRESENÇA DE GRANITOS PORTADORES DE ESTANHO}

A cassiterita (SnO2) é o mais importante minério de estanho e ocorre tanto em depósitos primários como em secundários. Granitos portadores de estanho exibem uma ampla distribuição geográfica no Cráton Amazônico, pertencentes às fases magmáticas dos eventos Uatumã e pós-Uatumã. Granitos do evento Uatumã são encontrados ao norte e ao sul da calha do rio Amazonas, no Estado do Pará, na porção sul de Roraima e Amapá (DAMASCENO, 1988).

A mina de Pitinga, no Estado de Roraima, é o mais importante jazimento estanífero do país, com reservas estaníferas de grande porte. Na bacia do rio Tapajós, também são encontrados granitos estaníferos, mas o Anuário Mineral Brasileiro não registra produção de cassiterita. Com relação ao evento pós-Uatumã, são conhecidos os granitos 
rondonianos, localizados na bacia do rio Madeira, os granitos da Serra da Providência, os granitos Teles Pires, na porção sul do Cráton Amazônico, os granitos Surucucus ao noroeste de Roraima. Na bacia do rio Xingu, no Estado do Pará, são encontrados maciços graníticos, sob a denominação de granito Velho Guilherme. Ocorreu aí uma intensa atividade de garimpagem e de lavra mecanizada.

No início do século XXI, as reservas minerais brasileiras são estimadas em 899,5 mil toneladas (Sn-contido), a terceira maior do mundo, após a China (2,1 milhão de toneladas) e a Malásia (1,2 milhão de toneladas). As reservas minerais brasileiras medidas, definidas com maior grau de precisão, somam 471,9 mil toneladas ę Sn-contido, com um teor médio do minério de 0,790 g de estanho $/ \mathrm{m}^{3}$ (DNPM, 2001). Em setembro de 2001, o DNPM aprovou a reavaliação das reservas de cassiterita do Grupo Paranapanema no Pitinga, no Estado do Amazonas. Houve um adicional expressivo de reservas nacionais, alcançando quase 900 mil de toneladas de estanho contido em minério, um incremento de aproximadamente 67\% em relação ao ano anterior.

O Gráfico 5, mostra a distribuição geográfica das reservas medidas brasileiras de estanho.

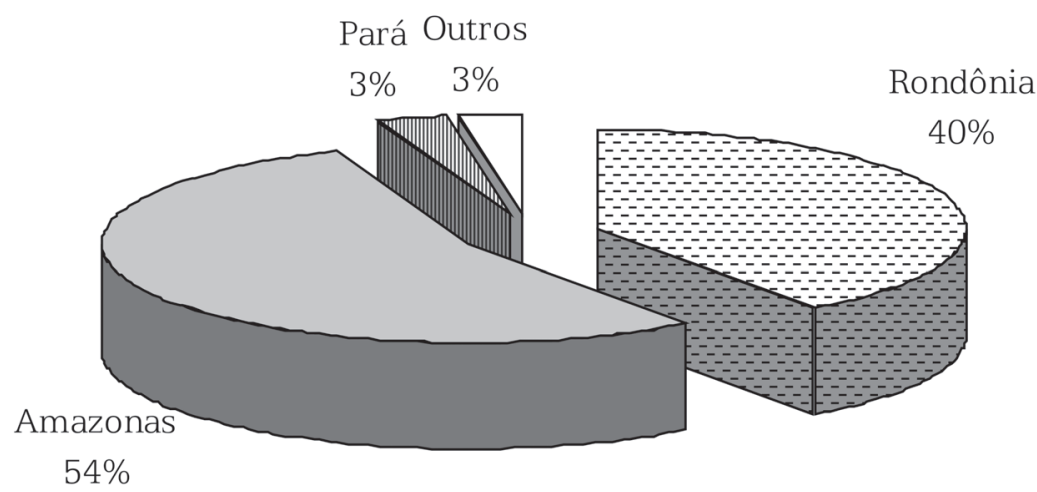

Gráfico 5: Brasil: reservas medidas, em Sn-contido (2000/2001). Fonte: Elaboração do autor com base no Balanço Mineral Brasileiro (DNPM, 2001).

As principais reservas medidas de cassiterita estão situadas na Região Norte. Em 2000, os Estados de Rondônia, do Amazonas e do Pará açambarcavam 97\% do total das reservas medidas brasileiras. As minas brasileiras de cassiterita mais importantes estão localizadas na Amazônia Oriental. No Estado de Rondônia (município de Ariquemes), está localizada a mina de Pitinga; no município de Presidente Figueiredo, no Estado do Amazonas, localiza-se a mina de Bom Futuro.

O Anuário Mineral Brasileiro de 2001 somente registra produção de cassiterita (estatísticas de 2000) nos Estados do Amazonas, de Rondônia e de Minas Gerais. Os dois Estados da Amazônia Oriental - Amazonas e Rondônia - produzem 99,2\% do total nacional. Embora as reservas medidas de cassiterita do Estado do Pará representem cerca de 3\% das reservas 
medidas do país, localizadas principalmente no município de São Félix do Xingu, não há registro oficial de produção do minério no Estado do Pará.

As reservas mundiais de estanho (Sn-contido) em 2001 são estimadas em 7,3 milhões (DNPM, 2001). A Figura 2 mostra a distribuição geográfica das reservas minerais mundiais. As reservas mais importantes estão localizadas em países do Sudeste Asiático China, Malásia, Indonésia e Tailândia (61\%) - e da América Latina Brasil, Peru e Bolívia (28\%). As reservas minerais brasileiras, localizadas principalmente na Região Amazônica, participam com 12\%. Entre 1970 e 2001, as reservas minerais mundiais deram um salto de $74 \%$.

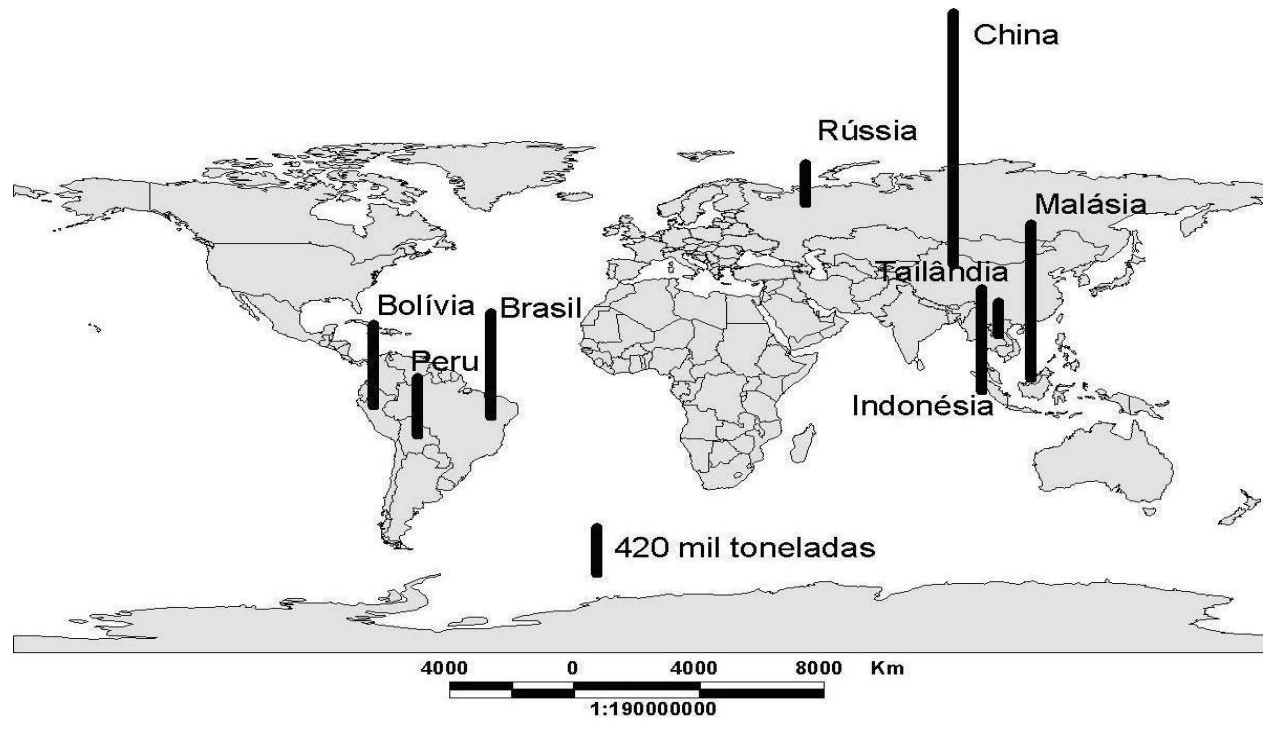

Figura 2: Reservas mundiais de estanho*.

Fonte: Elaboração do autor com base no Sumário Mineral (DNPM, 2001).

* Estanho contido no minério.

\section{A GEOGRAFIA E A EVOLUÇÃO DA PRODUÇÃO DE CASSITERITA NA AMAZÔNIA}

Em 1970, a produção amazônica atingia 4,6 mil toneladas de cassiterita, cerca de 99\% da produção nacional (a produção do Estado do Pará era insignificante), com a extração do minério realizada à base do sistema de matrícula (DNPM, 1973). Em abril de 1970, por meio da Portaria n. ${ }^{\circ}$ 195, o Ministério das Minas e Energia determinou o fechamento, a partir de 31 de março de 1971, da província estanífera de Rondônia para as atividades de extração de cassiterita, pelo regime de matrícula.

Uma década após, a província estanífera de Rondônia, conservavase hegemônica na produção de cassiterita, atingindo um patamar de 6 mil toneladas e sendo responsável pela produção nacional do minério. Os grupos empresariais - Paranapanema, Brascan, Brumadinho e Best 
- foram responsáveis por 97\% da produção nacional, no sistema de lavra mecanizada.

Com a entrada em operação da mina de Pitinga (1982), no Estado do Amazonas, perto da divisa com o Estado de Roraima, a Amazônia experimenta um surto de crescimento. Entre 1982 e 1983, a produção nacional de cassiterita dá um salto de quase 50\%. A produção dos Estados do Amazonas, de Rondônia e do Pará responde por 93\% do total nacional produzido. Um novo fato importante foi a descoberta, em 1987, da jazida de Bom Futuro, localizada no município de Ariquemes, no Estado de Rondônia. Em 1989, o Brasil tornar-se-ia o maior produtor de estanho do mundo, atingindo 54,7 mil toneladas de estanho em concentrado, com a Amazônia ainda mantendo a hegemonia na produção. A Figura 3, a seguir, mostra a localização geográfica das minas de Pitinga e Bom Futuro.

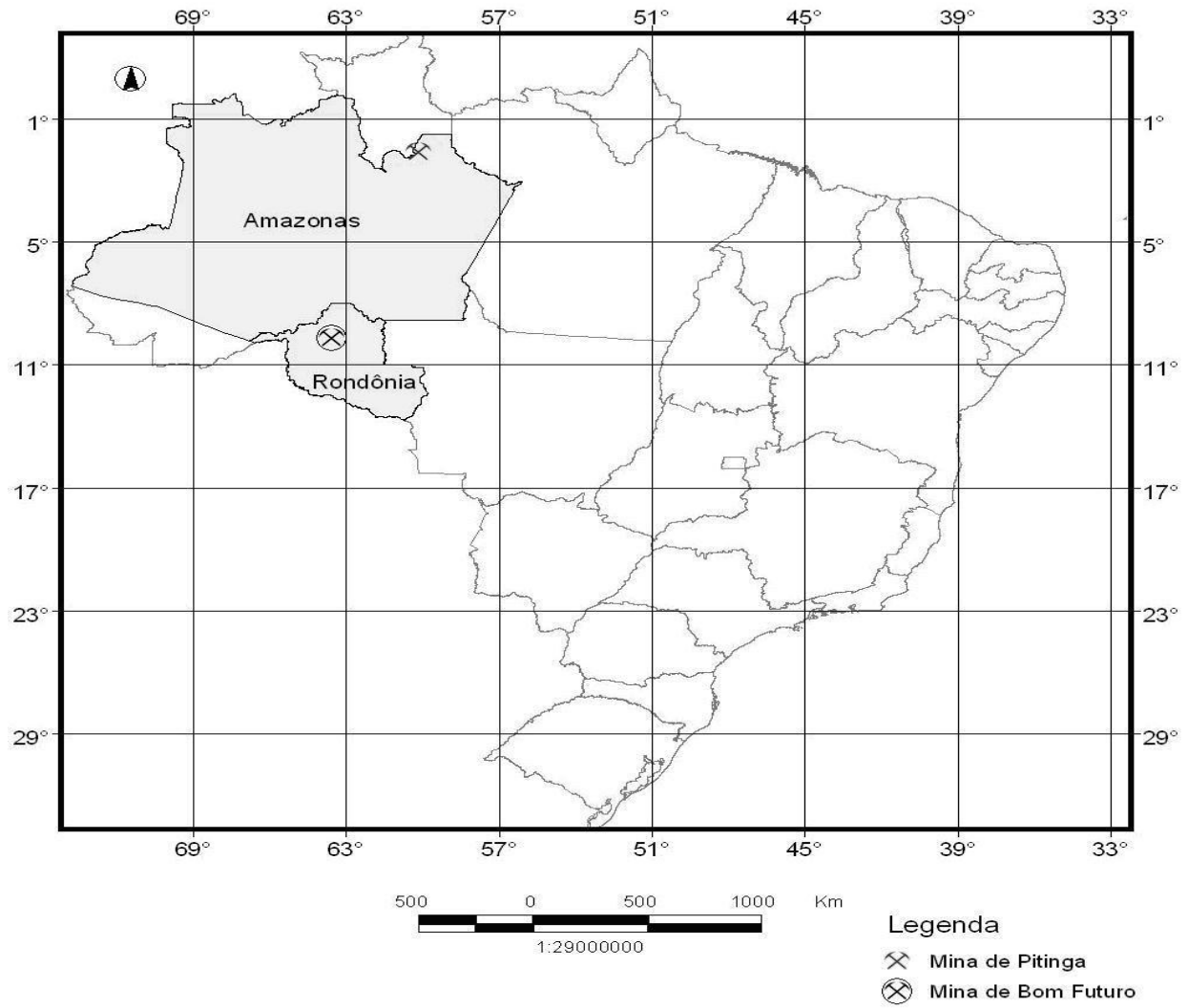

Figura 3: Localização geográfica das minas de estanho de Pitinga (AM) e Bom Futuro (RO).

Fonte: Elaboração do autor com base no Sumário Mineral (DNPM, 2001).

O boom da produção, sustentado pelas minas de Pitinga e Bom Futuro, foi efêmero. Entre 1989 e 1990, a produção nacional de estanho em concentrado exibiria uma queda de 23,4\% e, entre 1990 e 1991, um 
tombo de 27,1\%. Os seguintes fatores foram responsáveis pelo declínio da produção: a) queda no preço (LME) do metal de quase 36,4\%, em termos correntes, ao passar de US\$ 8.534/t em 1989 para US\$ 5.430/t em 2000 - no mesmo período, em valores constantes, o preço do metal sofria uma queda de 48\%; b) lavra ambiciosa, com esgotamento dos teores mais altos (mina de Bom Futuro) e exaustão das aluviões mais ricas da mina de Pitinga (DNPM, 2001). O preço da época (em 15/08/ 2003) do metal na Bolsa de Metais de Londres é de US 4.825/t.

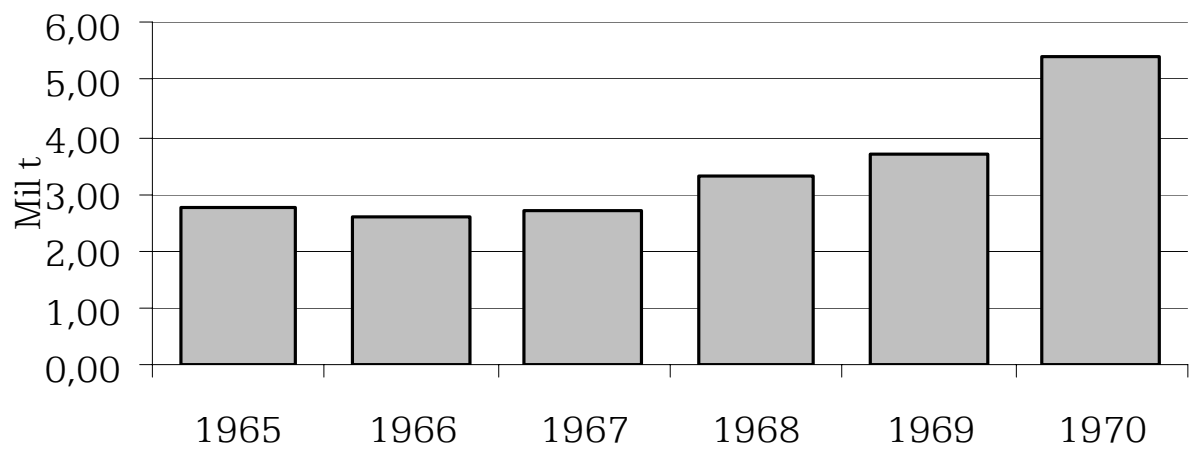

Gráfico 6: Brasil: produção de estanho contido em cassiterita (1965/1970).

Fonte : Elaboração do autor com base no Anuário Mineral Brasileiro (DNPM, 1975).

O Gráfico 6, acima, mostra a evolução da produção de estanho contido em cassiterita, no período 1965/1970. O ano de 1970 marca a data da estruturação da indústria de estanho no Brasil, principalmente na Amazônia Oriental. Nos estertores do sistema de extração de cassiterita, pelo sistema de matrícula, a produção garimpeira do minério de estanho (a província estanífera de Rondônia seria fechada às atividades de garimpagem no ano seguinte, no mês de março) alcança 5.421 toneladas (DNPM, 1973).

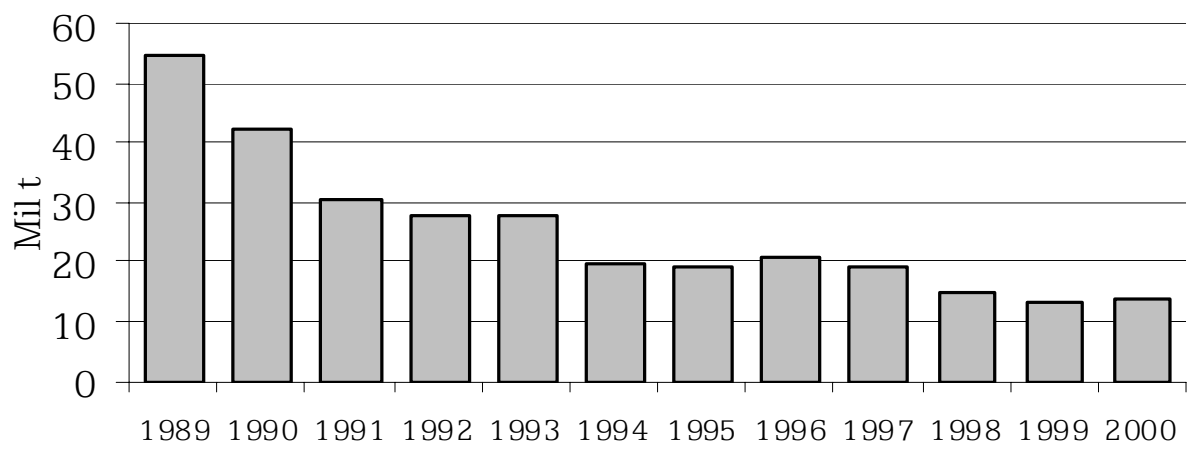

Gráfico 7: Brasil: produção de estanho contido em concentrado (1989/2000).

Fonte : Elaboração do autor com base no Anuário Mineral Brasileiro (DNPM, 2001). 
O Gráfico 7, objetiva ressaltar o apogeu e o recuo da produção nacional de estanho contido em concentrado, no período 1989/2000. E o Gráfico 8, permite inferir os principais eventos que afetaram os preços do estanho (valores correntes) ao longo do período 1960/1998. Entre 1960 e 1985, o preço do estanho era administrado pelo International Tin Agreement. Entre 1973 e 1980, os preços subiram, em decorrência da inflação em alta. Entre 1981 e 1982, ocorreu uma forte recessão, um desastre para a indústria mundial de estanho. O consumo foi afetado drasticamente.

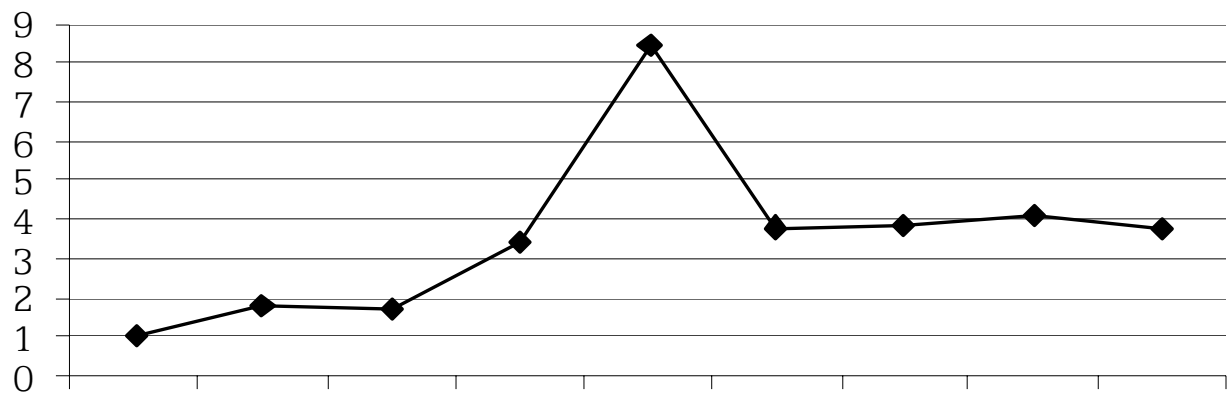

$\begin{array}{lllllllll}1960 & 1965 & 1970 & 1975 & 1980 & 1986 & 1990 & 1995 & 1998\end{array}$

Gráfico 8: Preço médio anual do estanho nos Estados Unidos

(1989/1999) (dólar por libra)*

* Para converter em dólar por quilograma, multiplicar por 2,20462.

O Gráfico 8, acima, permite inferir os principais eventos que afetaram os preços do estanho (valores correntes) ao longo do período 1960/1998. Entre 1960 e 1985, o preço do estanho era administrado pelo International Tin Agreement. Entre 1973 e 1980, os preços subiram, em decorrência da inflação em alta. Entre 1981 e 1982, ocorreu uma forte recessão, um desastre para a indústria mundial de estanho. O consumo foi afetado drasticamente.

O preço médio (em valor corrente) do metal (mercado dos Estados Unidos), cotado em US\$18.651/t no final dos anos 80, sofreu um colapso em 1986, ao ser fixado em US\$ 8.448/t - uma queda de quase 55\%. Entre 1989 e 1999, a produção nacional do minério de estanho sofre uma queda de 76\%, por causa da baixa performance das duas principais minas brasileiras - Pitinga (AM) e Bom Futuro (RO) -, em decorrência principalmente do esgotamento das porções mais ricas das duas minas.

Em 2000, a produção nacional de concentrado de estanho está concentrada em três empresas: a Mineração Taboca S/A, a Cia. Estanífera Brasileira (CESBRA) e a Estanho de Rondônia S/A (EBESA). A produção nacional de 13,7 mil toneladas é retirada da Amazônia, exceto uma pequena participação de Minas Gerais (0,2\%). 
O Gráfico 9, mostra a distribuição da produção nacional de concentrado de cassiterita, segundo as empresas produtoras do minério.

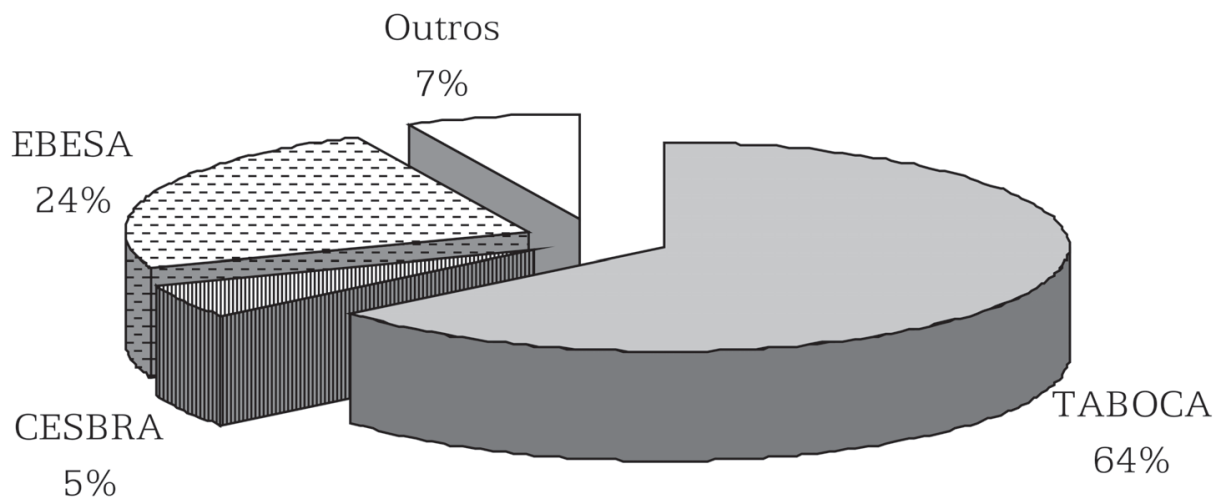

Gráfico 9: Brasil: empresas produtoras de concentrado de cassiterita (2000).

Fonte : Elaboração do autor com base no Sumário Mineral (DNPM, 2001).

A Mineração Taboca S/A (Grupo Paranapanema) é a detentora da concessão da lavra de cassiterita da Mina de Pitinga (AM). A Cia. Estanífera do Brasil (CESBRA) (Grupo BRANCAN) lavra a jazida de Santa Bárbara (RO), e a Empresa Brasileira de Estanho (EBESA) opera a Mina de Bom Futuro (RO), uma sociedade entre as empresas Mamoré, CESBRA e Best Metais e Soldas.

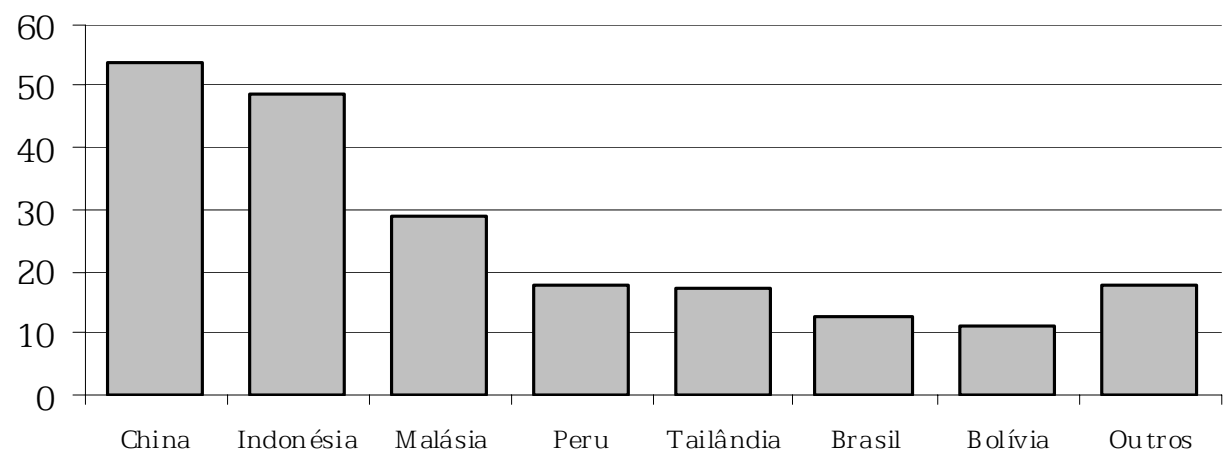

Gráfico 10: Produção mundial de estanho em concentrado (1999). Fonte : Elaboração do autor com base no SNIEE/ATCP (Association of Tin Producing).

O Gráfico 10 mostra a distribuição geográfica da produção de concentrado de estanho no ano de 1999. A produção mundial (1999) foi de 190,6 mil toneladas, oriunda principalmente do Sudeste Asiático China, Indonésia e Malásia - e da América Latina - Brasil, Peru e Bolívia. Entre 1990 e 1999, a produção de estanho cresceu a uma taxa media anual de 0,5\%. Deve-se ressaltar a performance da produção peruana, 
no mesmo período, com uma taxa anual de crescimento da ordem de 22\%. A empresa peruana Minsur SA, proprietária da mina de San Rafael, não enfrenta grandes dificuldades com a crise do estanho, haja vista o custo de produção em torno de US\$1.200/t e as reservas de 14 milhões de toneladas, com teor de 5\% Sn. A produção brasileira de estanho em concentrado experimentaria um taxa anual negativa de $-12 \%$ a.a.

\section{DISTRIBUIÇÃO DA CAPACIDADE INSTALADA DE PRODUÇÃO DE ESTANHO METÁLICO: A VERTICALIZAÇÃO LONGE DA AMAZÔNIA}

Ao final do século $\mathrm{XX}$, a capacidade instalada de produção de estanho metálico era da ordem de 32 mil toneladas (já havia atingido 54 mil em 1991). Como a produção em 2000 foi da ordem de 13,8 mil toneladas, os smelters operaram com uma ociosidade de aproximadamente 60\%. Toda a produção de concentrado é transformada dentro do país. Entretanto, quase toda a capacidade instalada de produção de estanho metálico está localizada na Região Sudeste, principalmente no Estado de São Paulo, pois uma única empresa, a Mamoré Mineração e Metalurgia Ltda., do Grupo Paranapanema, é responsável por $80 \%$ da capacidade nacional instalada de produção de estanho metálico, seguida pela Estanho de Rondônia S/A (ERSA), no Estado de Rondônia, município de Ariquemes, com 20\%. Com a escassez de minério (cassiterita), a indústria passou a operar com grande ociosidade. O Gráfico 11, abaixo, mostra a evolução da capacidade instalada nacional. A diminuição da capacidade reflete a queda da oferta nacional de estanho em concentrado.

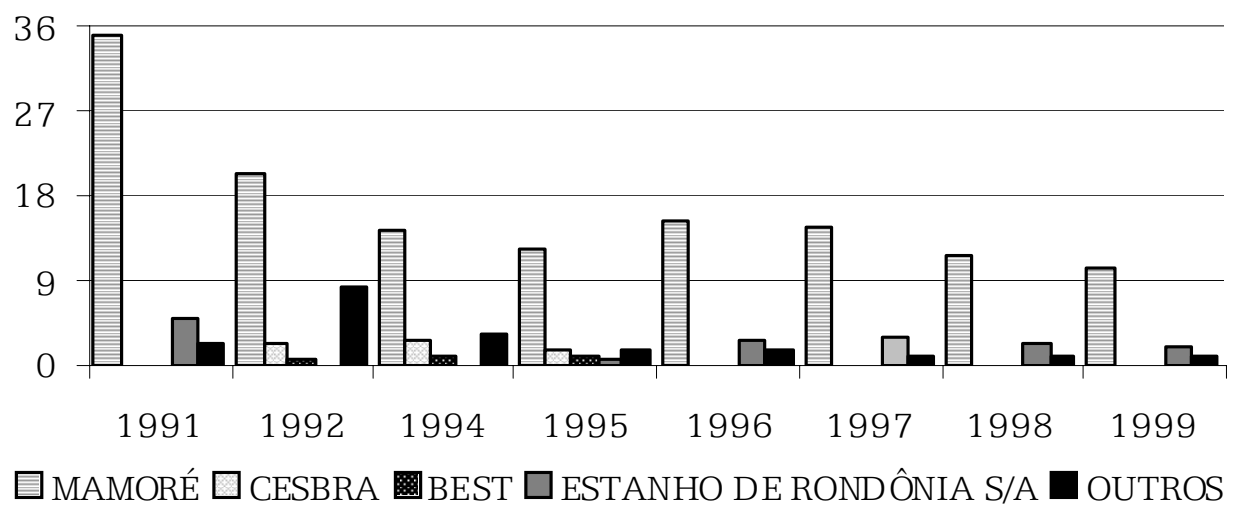

Gráfico 11: Brasil: capacidade instalada de produção de estanho metálico.

Fonte : Elaboração do autor com base no Balanço Mineral Brasileiro (DNPM, 2001). 


\section{TENDÊNCIAS DA DEMANDA DE MATÉRIAS-PRIMAS MINERAIS: UMA PARTILHA INJUSTA PARA OS PAÍSES POBRES}

Os países desenvolvidos, responsáveis por cerca de $22 \%$ da população mundial, açambarcam uma porcentagem muito maior do consumo anual de matérias-primas minerais. Aproximadamente 20\% da população mundial respondem por 80\% do consumo mundial de metais, uma situação iníqua para os países pobres. Uma avaliação do consumo nos países desenvolvidos e em desenvolvimento pode ser obtida em se examinando o consumo em relação à população. O Gráfico 12, abaixo, exibe a porcentagem da população das cinco maiores potencias econômicas - Estados Unidos, Japão, Alemanha, Reino Unido e França - e o consumo global de sete metais - alumínio, ferro, zinco, estanho, cobre, níquel e aço bruto.

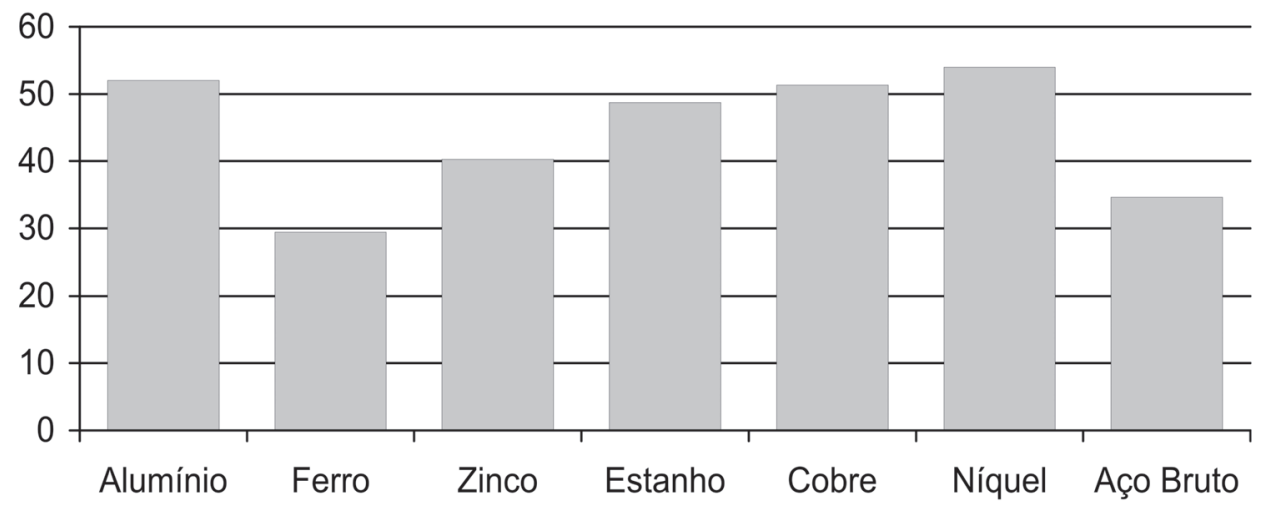

Gráfico 12: Consumo de matérias-primas minerais por cinco países selecionados: Estados Unidos, Japão, Alemanha, Reino Unido e França.

Fonte : Elaboração do autor com base no World Resources Institute (WRI, 1992).

O consumo per capita das principais matérias-primas é muito maior nas nações do mundo ocidental, principalmente nos Estados Unidos, comparativamente aos países em desenvolvimento.

A Tabela 1, abaixo, mostra a disparidade do consumo per capita de aço e alumínio nos Estados Unidos e na Europa Ocidental, quando comparada à média mundial. O consumo brasileiro de alumínio per capita, em 1994, foi de 2,8kg, aproximando-se do consumo médio mundial, mas, comparando-se com o consumo per capita dos Estados Unidos, o consumo americano per capita de alumínio é 10 vezes superior ao brasileiro. Comparando-se o consumo per capita de estanho no Brasil e no Japão, constata-se que o consumo per capita japonês é seis vezes maior, 0,04 e 0,23, respectivamente. 
Tabela 1: Consumo per capita de matérias-primas selecionadas (1994).

\begin{tabular}{c|c|c|c|c|c}
\hline & \multicolumn{4}{|c|}{ Consumo médio per capita $(\mathrm{kg})$} & \multicolumn{2}{c}{$\begin{array}{c}\text { Consumo médio per capita } \\
\text { comparado com a média } \\
\text { mundial }\end{array}$} \\
\cline { 2 - 6 } & $\begin{array}{c}\text { Estados } \\
\text { Unidos }\end{array}$ & $\begin{array}{c}\text { Europa } \\
\text { Ocidental }\end{array}$ & Mundo & $\begin{array}{c}\text { Estados } \\
\text { Unidos }\end{array}$ & $\begin{array}{c}\text { Europa } \\
\text { Ocidental }\end{array}$ \\
\hline Matéria-prima & 353 & 379 & 129 & $2.8 \mathrm{x}$ & $2.9 \mathrm{x}$ \\
Aço & 25 & 17,2 & 3,4 & $7.4 \mathrm{x}$ & $5.1 \mathrm{x}$ \\
Alumínio &
\end{tabular}

Fontes: Bureau of Mines, Iron and Steel Institute (ISI) e World Resources Institute (WRI).

A Tabela 2, a seguir, objetiva mostrar a relação entre o consumo global de metais selecionados - alumínio, aço, cobre, chumbo, níquel e estanho - e a população mundial. Uma relação com valor 1 indica que o consumo está crescendo no mesmo ritmo da população. Valores maiores ou menores que 1 indicam que as taxas de crescimento do consumo dos metais selecionados são maiores ou menores com relação ao crescimento populacional.

Tabela 2: Consumo global de metais selecionados e população mundial.

\begin{tabular}{ccc|c|c|c|c|c|c}
\hline Período & Alumínio & Aço & Cobre & Chumbo & Níquel & Zinco & Estanho \\
\hline $1961 / 1970$ & 1,85 & 0,39 & 1,19 & 1,2 & 1,49 & 1,29 & 0,94 \\
$1971 / 1980$ & 1,21 & 1,05 & 1,09 & 1,14 & 1,15 & 1,01 & 0,83 \\
$1981 / 1990$ & 1,13 & 0,93 & 0,97 & 0,93 & 1,15 & 0,99 & 0,99 \\
$1971 / 1990$ & 1,29 & 0,95 & 1,06 & 1,02 & 1,21 & 0,97 & 0,77 \\
$1961 / 1990$ & 2,5 & 1,28 & 1,23 & 1,24 & 1,62 & 1,27 & 0,71 \\
$1961 / 1980$ & 2,35 & 1,42 & 1,27 & 1,38 & 1,53 & 1,32 & 0,77 \\
\hline
\end{tabular}

Fonte: Raw Material and the Environment, University of Minnesota (1998).

Com base nos índices da Tabela 2 acima, especificamente do período de quatro décadas (1961/1990), verifica-se que todos os metais exibem valores maiores que um, o que indica que o consumo dos metais selecionados está crescendo a uma taxa superior à da população mundial, exceto com relação ao estanho $(0,71)$, que exibe taxa menor que um, a pior performance entre os metais selecionados.

A Tabela 3 compara o crescimento médio anual do PIB e o consumo de metais selecionados - alumínio, cobre, chumbo, níquel, aço e zinco (em porcentagem) dos países em desenvolvimento. 
Tabela 3: $\quad$ Crescimento médio anual do PIB e consumo de metais (\%) nos países em desenvolvimento.

\begin{tabular}{c|c|c|c|c|c|c|c}
\hline Período & PIB & Alumínio & Cobre & Chumbo & Níquel & Aço & Zinco \\
\hline $1960 / 1973$ & 6,7 & 13,8 & 5,7 & 7 & 21,7 & 8,3 & 6,5 \\
$1973 / 1979$ & 5,1 & 12,9 & 9,9 & 9,7 & 7,9 & 8 & 7,4 \\
$1979 / 1987$ & 2,8 & 7,9 & 8 & 3,8 & 18 & 1,4 & 4,6 \\
\hline
\end{tabular}

Fonte: Raw Material and the Environment, University of Minnesota (1998).

Comparações entre o consumo de matérias-primas e o PIB (valor de bens e serviços produzidos dentro do país) permitem avaliar a importância das matérias-primas na economia do país ao longo do tempo. Os índices dos metais nos países em desenvolvimento geralmente está crescendo a um ritmo superior ao do PIB. No período 1979/1987, apenas o aço cresceu a uma taxa inferior à do PIB.

6 O INTERNATIONAL TIN COUNCIL (ITC): UMA ORGANIZAÇÃO COM A MISSÃO DE MANTER O EQUILÍBRIO ENTRE PRODUTORES E CONSUMIDORES, EVITANDO GRANDES FLUTUAÇÕES NO PREÇO DO ESTANHO

Os primeiros acordos (agreements) do estanho datam de 1921. Até 1956, quando foi realizado o Primeiro Acordo Internacional de Estanho, os acordos entre países produtores e consumidores de estanho eram informais e esporádicos. Durante quase três décadas, de 1956 a 1985 (quando ocorreu o colapso), o ITC exerceu um considerável controle nos preços da commodity, com a utilização dos seguintes instrumentos de intervenção no mercado de estanho: a) definição de preços de intervenção, máximo e mínimo, b) geração de um estoque regulador (em metal e em dinheiro) e c) controle das exportações. Também foi criado o Conselho Internacional de Pesquisa de Estanho com o objetivo de gerar novos acordos. O ITC era capaz de suportar os preços durante os períodos de preços baixos, comprando estanho para o estoque (buffer stockpile). Por outro lado, em períodos de alta do preço, o ITC vendia estanho do estoque. Tratava-se de uma estratégia de preços administrados, objetivando assegurar um fluxo adequado de estanho para os países consumidores e um lucro justo para os países produtores.

Com o advento das latas de alumínio, que substituíram as latas de folha-de-flandres (tinplate), o uso de polímeros e o aumento crescente da reciclagem, a demanda sofreu uma queda dramática no início dos anos 80. O governo americano agravou a situação, ao colocar parte do seu estoque estratégico no mercado, deprimindo os preços (DNPM, 1983). O ITC não pôde mais manter o preço. Em 1985, o ITC atingia seu limite de crédito. Ocorre a "crise do estanho", e o metal deixa de 
ser cotado pela Bolsa de Londres (LME) por cerca de três anos. O ITC é dissolvido em 1990. O preço do metal volta ao ambiente de mercado livre.

\section{A ASSOCIAÇÃO DOS PAÍSES PRODUTORES DE ESTANHO (ATPC): UMA TENTATIVA DE REORGANIZAÇÃO DO MERCADO DE ESTANHO}

A Associação dos Países Produtores de Estanho (Association of Tin Producing Countries - ATPC) foi criada em Londres em 1983, congregando os principais países produtores do metal (Austrália, Bolívia, China, Indonésia, Malásia, Tailândia, Nigéria e Zaire), responsáveis por cerca de $80 \%$ da produção mundial de estanho de minas. A ATPC tinha como propósito promover a pesquisa e o desenvolvimento e elevar o consumo mundial de estanho, principalmente de dois produtos - solda para a indústria eletrônica e folha-de-flandres (tinplate) para a fabricação de latas. O ITC mantinha a política de sustentação dos preços do metal, impondo controles de exportação e controlando o estoque regulador (buffer stocks). A estratégia do ITC era solapada tanto pela produção dos países não-membros como pelo contrabando do estanho no Sudeste Asiático.

Três anos após a criação da ATPC, membros da entidade decidiram introduzir o Supply Rationalisation Scheme (SRS), uma estratégia para restringir a produção de estanho em países membros, reduzindo os níveis dos estoques no mercado. A Austrália, membro fundador, resolve não aceitar controles de exportações, sem questionar, entretanto, a essência do SRS (em 1996 o SRS seria suspenso).

Com a crise do estanho e a extinção do ITC, coube à ATPC a responsabilidade pela reorganização do mercado. As ações da ATPC tiveram êxito. Desde que o preço do metal entrou em colapso há dez anos, os principais países produtores de estanho concordaram em fixar cotas anuais e em reduzir os estoques. Os preços subiram significativamente em 1995, e os países produtores concordaram em suspender o sistema de cotas de exportação em junho de 1996 (entre 1995 e 1996, o preço do metal aumentou em quase 13\%, US\$ 8.137 e US\$ 9.162, no mercado americano).

O Decreto Legislativo n. ${ }^{\circ}$ 64, de 1997, publicado no DOU de 5 de novembro de 1997, aprovou o texto do Acordo Constitutivo da Associação dos Países Produtores de Estanho, celebrado em 29 de março de 1983, em Londres, com os seguintes objetivos: a) obter retornos remunerativos e eqüitativos para os produtores de estanho; b) facilitar a cooperação na comercialização do metal; c) manter e expandir a efetividade de utilização e de custos do estanho na tecnologia moderna; 
d) estimular as atividades de processamento e de manufatura baseadas no estanho nos países membros; e) promover uma maior auto-suficiência e flexibilidade dos países membros na indústria do estanho.

Em 14 de dezembro de 1999, por meio do Decreto Legislativo n. ${ }^{\circ}$ 182, é aprovado o acordo sobre a sede, celebrado entre o Governo Brasileiro e a Associação dos Países Produtores de Estanho, em Brasília,

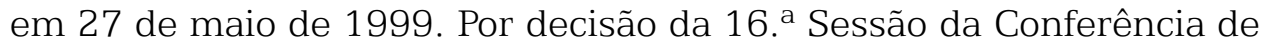
Ministros da Associação dos Países Produtores de Estanho, realizada no Rio de Janeiro, em setembro de 1998, foi decidida a transferência da sede da ATPC para o Rio de Janeiro, a partir de junho de 1999.

A saída de vários membros da ATPC - Austrália, Tailândia e Indonésia (1996), Malásia (1997) - resultou no enfraquecimento da entidade. Em 1998, a ATPC tinha como países membros o Brasil, a China (membro a partir de 1994), o Congo e a Nigéria. Com dois grandes produtores como membros - Brasil (grande produtor) e China (o maior produtor mundial de estanho) -, a ATPC passou a acreditar que poderia controlar melhor os esforços para restringir o suprimento de estanho, diminuindo o excesso de estoques.

O colapso do preço do metal ao longo dos últimos anos afetou profundamente a indústria do estanho, e a APCT afundou junto com a crise do estanho em 2001.

Com o colapso da APCT, a ITRI Ltd., anteriormente denominada International Tin Research Institute, torna-se a única entidade representativa dos produtores e consumidores mundiais de estanho. A ITRI Ltd., uma instituição privada desde 1993, está envolvida na pesquisa, no desenvolvimento e no marketing de tecnologias baseadas no estanho. A atuação da organização vai além das regiões tradicionais - Europa, Estados Unidos e Japão -, mas envolve os principais países produtores - China, Indonésia e Malásia -, responsáveis por cerca de 64\% da produção mundial do metal em 2000 (USGS 2001), que são, também, importantes consumidores do metal (a China responde por 20\% do consumo mundial, sendo o mercado dos três países asiáticos juntos tão grande quanto o dos Estados Unidos). 


\section{REFERÊNCIAS}

Departamento Nacional da Produção Mineral - DNPM. Anuário mineral brasileiro. Brasília, 1975.

Departamento Nacional da Produção Mineral - DNPM. Sumário mineral. Brasília, 2000, 2001.

Departamento Nacional da Produção Mineral - DNPM. Balanço Mineral Brasileiro. Brasília, 2001.

GFMS. Tin World Supply Demand. London, 2003.

GRUPO PARANAPANEMA. Disponível em:<http://www.paranapanema. com.br/>. Acesso em: 9 out. 2003.

SNIEE/ATCP. Estanho no Mundo: Evolução do Mercado. Mineração e Metalurgia.2000.

UNIVERSITY OF MINNESOTA. Raw Material and the Environment. Disponível em:http://http://www.forestprod.org/ Acesso em: 9 out. 2003.

USGS.Tin. Mineral Commodities Summaries, January, 2002.

USGS. Tin. Mineral Commodities Summaries, January, 2001.

WRI. Per capitaConsumption.Washington, 1994. 